\section{Coronavirus HKU1 in Children, Brazil, 1995}

To the Editor: Coronavirus HKU1 is a newly identified human coronavirus $(\mathrm{HCoV})$ that was reported first in 2005 in Hong Kong Special Administrative Region, People's Republic of China; later in Australia, Europe, and the United States, and more recently in Brazil, demonstrating a global distribution (1-3). We examined the circulation of $\mathrm{HCoV}$ in Brazil and the possible presence of the new $\mathrm{HCoV}$ types, with special attention to coronavirus HKU1, in samples collected back to 1995 , tested by using universal coronavirus PCR.

The epidemiologic profile of $\mathrm{HCoV}$ was retrospectively investigated with samples collected during March-December 1995 in a pediatric ward of University Hospital, São Paulo University, São Paulo, Brazil. The Ethics Committee on Research Involving Human Subjects of the Institute of Biomedical Sciences, University of São Paulo, approved the study. Samples of nasopharyngeal aspirates were collected from 169 hospitalized children, ages 7 days -15 years, of whom 104 had respiratory symptoms, 23 had enteric disease, and 3 had both (4). The mean age of the study population was 19.6 months (median 7 months). Viral nucleic acid was extracted from specimens by using Trizol (Invitrogen, Carlsbad, CA, USA) following the manufacturer's instructions. Total RNA was then submitted to reverse transcription PCR with a High-Capacity cDNA Archive Kit (Applied Biosystems, Foster City, CA, USA) by using random primers according to the manufacturer's instructions. The cDNA obtained was screened with primers able to amplify a 220-bp product in the conserved polymerase region of all known HCoVs (5) and other coronaviruses (e.g., bovine coronavirus). We used cDNA obtained from cultured human rectal tumor cell line HRT-18G cells inoculated with bovine coronavirus strain Kakegawa as positive controls for PCR.

In an attempt to improve the sensitivity of HKU1 detection, we analyzed samples with negative results by PCR with a nested PCR specific for coronavirus HKU1. This nested assay was designed on an alignment of our HKU1-positive sample sequence (BRA169) and different HKU1 genotype sequences deposited in GenBank. Primers Fn-HKU1 (forward 5'-CGTGCYA TGCCAAATATTTTGCG-3', HKU1NC 006577, nt 15433-15454) and Rn-HKU1 (reverse 5'-TAGCAACC GCCACACATAAC-3', HKU1-NC_ 006577, nt 15562-15581) produced an amplicon of $149 \mathrm{bp}$. The nested PCR was run in a $50-\mu$ L reaction comprising $10 \mu \mathrm{L}$ of PCR product, 1.5 units of DNA Polymerase (Biotools, Madrid, Spain), $1 \mu \mathrm{mol} / \mathrm{L}$ of each primer, $200 \mu \mathrm{mol} / \mathrm{L}$ of each dNTP (Applied Biosystems), $2 \mathrm{mmol} / \mathrm{L} \mathrm{MgCl}$, and $1 \times$ buffer. PCR mixtures were heated to $95^{\circ} \mathrm{C}$ for $5 \mathrm{~min}$, followed by 35 cycles of $1 \mathrm{~min}$ at $95^{\circ} \mathrm{C}, 30 \mathrm{~s}$ at $62^{\circ} \mathrm{C}$, and $40 \mathrm{~s}$ at $72^{\circ} \mathrm{C}$, followed by a final 10 min at $72^{\circ} \mathrm{C}$. Clinical samples positive for HKU1 were used as positive controls in the HKU1 nested PCR. All fragments obtained from PCR and nested PCR were analyzed in a $\%$ (wt/ vol) agarose gel by electrophoresis, stained with $0.5 \mu \mathrm{g} / \mathrm{mL}$ of ethidium bromide, and subsequently sequenced to confirm the type of coronavirus. Nucleotide sequencing reactions were performed on both amplicon strands by using an ABI PRISM Big Dye Cycle Sequencing Kit with the ABI PRISM 3100 automatic sequencer (Applied Biosystems).

Six (3.6\%) samples tested positive for HCoV-HKU1: 2 samples by PCR and 4 by nested PCR. HCoV types 229E, OC43, and NL63 were not detected in any sample by PCR. Samples positive for $\mathrm{HCoV}$ were associated with pertussis, pneumonia, bronchiolitis, and diarrhea (Table).

In a recent review, an analysis of 18 studies indicated that the median (range) incidence of HCoV-HKU1 was $0.9 \%(0 \%-4.4 \%)(2)$, which is similar to the detection rate in our study. To our knowledge, the only study that has screened for HKU1 in Brazil found that $0.48 \%$ of children were positive for HKU1 (3), which is lower than our results.

Although we did not detect other $\mathrm{HCoV}$ types, all $\mathrm{HCoV}$ types were detected previously in Brazil in samples collected during 2006-2008 $(3,6)$. The absence of detection of 229E, OC43, and NL63 HCoV might have resulted from the seasonality and natural viral year cycle or from the characteristics of the children studied

\begin{tabular}{|c|c|c|c|c|c|}
\hline $\begin{array}{l}\text { Specimen no.: HCoV } \\
\text { strain by pol analyses }\end{array}$ & Age/sex & $\begin{array}{l}\text { Sample } \\
\text { collection date }\end{array}$ & Clinical diagnosis & Co-infections & $\begin{array}{l}\text { Detection method, fragment } \\
\text { sequenced }\end{array}$ \\
\hline 09: HKU1A & $3 \mathrm{mo} / \mathrm{F}$ & Mar & Pertussis & ND & Nested PCR, 143 bp \\
\hline 37: HKU1A & $2 \mathrm{mo} / \mathrm{M}$ & Apr & $\begin{array}{c}\text { Bronchiolitis plus } \\
\text { bronchopneumonia }\end{array}$ & RSV & Nested PCR, 143 bp \\
\hline 90: HKU1B & $4 \mathrm{mo} / \mathrm{M}$ & Jul & Upper respiratory infection & ND & Nested PCR, 143 bp \\
\hline 99: HKU1 B & $9 \mathrm{y} / \mathrm{M}$ & Jul & Pleural effusion pneumonia & ND & Nested PCR, 143 bp \\
\hline 104: HKU1 A & $2 \mathrm{mo} / \mathrm{F}$ & Jul & Pertussis & ND & Pancoronavirus PCR, 143 bp \\
\hline 169: HKU1B & $3 \mathrm{y} / \mathrm{F}$ & Nov & Fever, diarrhea & Worms & Pancoronavirus PCR, $173 \mathrm{bp}$ \\
\hline
\end{tabular}

${ }^{*} \mathrm{HCoV}$, human coronavirus; ND, not detected; RSV, respiratory syncytial virus. 
because we included samples from children hospitalized with or without respiratory disease.

BLAST search (www.ncbi.nlm. nih.gov/blast/Blast.cgi) and phylogenetic analysis of amplicons from PCR and nested PCR indicated that samples were positive for HKU1 genotype B (samples BRA169, BRA90, and BRA99) or HKU1 genotype A (samples BRA09, BRA37, and BRA104). The sequences obtained in this study have been deposited in GenBank under accession nos. FJ931534.1 (BRA169), GU904424 (BRA37), GU904427 (BRA104), GU904423 (BRA09), GU904425 (BRA90), and GU904426 (BRA99).

This may be the oldest collection of human samples in which HKU1 has been detected. To our knowledge, the oldest previous sample positive for HCoV-HKU1 was detected in children in Finland during 1996-1998, without an exact date specified (7). Retrospective studies also have been conducted in the United States and Greece that showed the HKU1 virus in different countries in Europe and North America before its discovery $(8,9)$. We have confirmed the circulation of HKU1 coronaviruses in children in Brazil in 1995.

This work was supported by the São Paulo Research Foundation and the Coordination for the Improvement of University Level Personnel.

\section{Luiz G. Góes, Edison L. Durigon, Angélica A. Campos, Noely Hein, Saulo D. Passos, and José A. Jerez \\ Author affiliations: Universidade de São Paulo, São Paulo, Brazil (L.G. Góes, E.L. Durigon, A.A. Campos, N. Hein, J.A. Jerez); and Faculdade de Medicina de Jundiai, Jundiai, Brazil (S.D. Passos)}

DOI: 10.3201/eid1706.101381

\section{References}

1. Woo PC, Lau SK, Chu CM, Chan KH, Tsoi HW, Huang Y, et al. Characterization and complete genome sequence of a novel coronavirus, coronavirus HKU1, from patients with pneumonia. J Virol. 2005;79:884-95. doi:10.1128/ JVI.79.2.884-895.2005

2. Woo PC, Lau SK, Yip CC, Huang Y, Yuen $\mathrm{K}$. More and more coronaviruses: human coronavirus HKU1 viruses. Viruses. 2009;1:57-71. doi:10.3390/v1010057

3. Albuquerque MC, Pena GP, Varella RB, Gallucci G, Erdman D, Santos N. Novel respiratory virus infections in children, Brazil. Emerg Infect Dis. 2009;15:806-8. doi:10.3201/eid1505.081603

4. Hein N. Epidemiological aspects of the respiratory viruses infection in a pediatric ward [dissertation] [in Portuguese]. São Paulo (Brazil): Universidade de São Paulo; 1997.

5. Canducci F, Debiaggi M, Sampaolo M, Marinozzi MC, Berre S, Terulla C, et al. Two-year prospective study of single infections and co-infections by respiratory syncytial virus and viruses identified recently in infants with acute respiratory disease. J Med Virol. 2008;80:716-23. doi:10.1002/jmv.21108

6. Bellei N, Carraro E, Perosa A, Watanabe A, Arruda E, Granato C. Acute respiratory infection and influenza-like illness viral etiologies in Brazilian adults. J Med Virol. 2008;80:1824-7. doi:10.1002/jmv.21295

7. Ruohola A, Waris M, Allander T, Ziegler $\mathrm{T}$, Heikkinen T, Ruuskanen O. Viral etiology of common cold in children, Finland. Emerg Infect Dis. 2009;15:344-6. doi:10.3201/eid1502.081468

8. Esper F, Weibel C, Ferguson D, Landry ML, Kahn JS. Coronavirus HKU1 infection in the United States. Emerg Infect Dis. 2006;12:775-9.

9. Papa A, Papadimitriou E, Luna LK, Al Masri M, Souliou E, Eboriadou M, et al. Coronaviruses in children, Greece. Emerg Infect Dis. 2007;13:947-9.

Address for correspondence: Edison L. Durigon, University of São Paulo, 1374 ICB-II, CEP: 05508-900, São Paulo, São Paulo, Brazil; email: eldurigo@usp.br

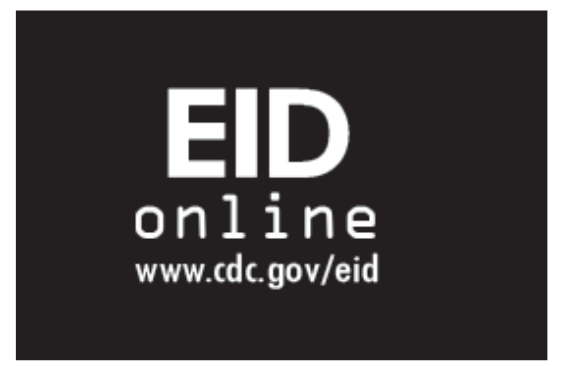

\section{Macrolide Resistance- associated 235 rRNA Mutation in Mycoplasma genitalium, Japan}

To the Editor: Mycoplasma genitalium is now recognized as a serious pathogen in sexually transmitted infections $(1,2)$. Azithromycin regimens have been commonly used for treatment of $M$. genitalium infections (3). However, failure of azithromycin treatment has been reported in cases of $M$. genitalium-positive nongonococcal urethritis (NGU) $(4,5)$, and macrolideresistant strains of $M$. genitalium have been isolated from case-patients in Australia, Sweden, and Norway for whom azithromycin treatment has failed $(4,5)$. In these strains, mutations in the 23S rRNA gene were associated with macrolide resistance, and mutations in ribosomal protein genes L4 and L22 were also found (5). Surveillance for antimicrobial resistance of M. genitalium is essential to identify antimicrobial resistant strains and to then determine appropriate treatment. Coculture of patient specimens with Vero cells has improved the primary isolation rate of $M$. genitalium from clinical specimens and offered some current clinical strains for antimicrobial drug susceptibility testing (6). To determine their antimicrobial susceptibilities, a molecular real-time PCR method has been developed $(7,8)$. However, isolating M. genitalium from clinical specimens and antimicrobial drug susceptibility testing of clinical isolates remain labor-intensive, time-consuming tasks. In addition, no methods are available to directly determine antimicrobial drug susceptibilities of $M$. genitalium in clinical specimens. To monitor macrolide susceptibilities in clinical 